\title{
Chromosome polymorphism and complements in populations of Girardia species (Platyhelminthes, Tricladida, Paludicola) from Southern Brazil
}

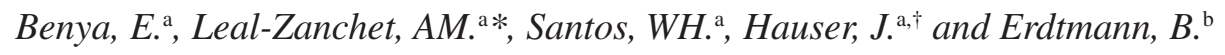 \\ aPrograma de Pós-Graduação em Biologia, Instituto de Pesquisa de Planárias, \\ Universidade do Vale do Rio dos Sinos, \\ Av. Unisinos, 950, CEP 93022-000, São Leopoldo, RS, Brazil \\ 'PPGGBM, Universidade Federal do Rio Grande do Sul, Porto Alegre, RS and \\ Centro de Biotecnologia da Universidade de Caxias do Sul, Caxias do Sul, RS, Brazil \\ *e-mail: zanchet@unisinos.br \\ Received March 9, 2006 - Accepted July 11, 2006 - Distributed December 1, 2007
}

(With 2 figures)

\begin{abstract}
The karyotypes of four species of freshwater triclads of the genus Girardia (Platyhelminthes), i.e. G. schubarti, G. tigrina, G. anderlani, and G. biapertura, from populations of different localities of the Rio Grande do Sul State, in southern Brazil, were analyzed. The karyotype of G. biapertura is presented for the first time. Three basic complements of 4,8 , and 9 chromosomes were found. Diploids, triploids, or mixoploids $(2 n / 3 n)$ specimens were frequently detected in these populations. The basic chromosomal complement of $n=9$ was verified in two different species (G. biapertura and G. anderlani), presenting a large acrocentric chromosome which is rare in the family Dugesiidae. An intra and interspecific chromosomal variability was also detected and its evolutionary implications are discussed.
\end{abstract}

Keywords: freshwater planarians, cytogenetics, genetic plasticity, chromosome variability.

\section{Polimorfismo e complementos cromossômicos em populações de espécies de Girardia (Platyhelminthes, Tricladida, Paludicola) do sul do Brasil}

\begin{abstract}
Resumo
Os cariótipos de quatro espécies de planárias de água doce do gênero Girardia (Platyhelminthes), a saber, G. schubarti, G. tigrina, G. anderlani e G. biapertura, de populações ocorrentes em diferentes locais do estado do Rio Grande do Sul, na região sul do Brasil, foram analisados. O cariótipo de G. biapertura é apresentado pela primeira vez. Foram observados três complementos básicos, de 4, 8 e 9 cromossomos. Espécimes diplóides, triplóides e mixoplóides (2n/3n) foram observados freqüentemente nessas populações. O complemento cromossômico básico de $\mathrm{n}=9$ foi verificado em duas espécies ( $G$. biapertura e $G$. anderlani), apresentando um grande cromossomo acrocêntrico que é raro na família Dugesiidae. Também foi observada certa variabilidade cromossômica, tanto intra- como interespecífica, cujas implicações evolutivas são discutidas.
\end{abstract}

Palavras-chave: planárias de água doce, citogenética, plasticidade genética, variabilidade cromossômica.

\section{Introduction}

Systematic cytogenetic research concerning species of the genus Girardia (Dugesiidae) in south Brazil date from the 1970's (Pereira, 1970; Kawakatsu et al., 1981, 1983, 1984). Major karyological investigations have been done in taxonomic studies of freshwater planarians (Kawakatsu et al., 1981, 1983, 1984). From the six known species occurring in the Brazilian southern region, only Girardia schubarti (Marcus, 1946),
Girardia tigrina (Girard, 1850), and Girardia anderlani (Kawakatsu and Hauser, 1983) were studied from a cytogenetic point of view (Pereira, 1970; Kawakatsu et al., 1981, 1983, 1984).

Except for the data on a few populations of G. schubarti (Kawakatsu et al., 1984), little is known about the intraspecific cytogenetic variability in Brazilian Dugesiidae. The interspecific variability is also poorly

†n memoriam 
known and the method used in earlier studies for chromosome dispersion ("squash" method) did not yield the best results to analyze the chromosome morphology.

The purpose of this research was to analyze the karyological components of four freshwater planarian species from the northeast region of the Rio Grande do Sul State, (Southern Brazil), with the objective to recognize chromosome morphology including inter and intra species variability. Three of these species, G. schubarti, G. tigrina, and G. anderlani, are the most common in the Southern Brazil area. Girardia biapertura Sluys, 1997 is known only from its type-locality.

\section{Material and Methods}

We studied 20 specimens of four species of Dugesiidae (i.e., at least three specimens of each population) from different localities of the northeast region of the Rio Grande do Sul State (Figure 1), Southern Brazil. Specimens of Girardia schubarti (Marcus, 1946) were obtained from two populations - a population from Arroio Lajeado of the National Forest of São Francisco de Paula, São Francisco de Paula $\left(29^{\circ} 27^{\prime} \mathrm{S}\right.$ and $\left.51^{\circ} 30^{\prime} \mathrm{W}\right)$, and a second population from Linha Júlio de Castilho, Salvador do Sul (29 $26^{\circ}$ 'S and $\left.51^{\circ} 29^{\prime} \mathrm{W}\right)$. Specimens of Girardia tigrina (Girard, 1850) were obtained from a population of Arroio Forqueta, Gramado $\left(29^{\circ} 22^{\prime} \mathrm{S}\right.$ and $\left.50^{\circ} 54^{\prime} \mathrm{W}\right)$ as well as from a laboratory stock at UNISINOS, São Leopoldo. Specimens of Girardia biapertura Sluys, 1997 were obtained from the type-locality, in a narrow stream at São Sebastião do Caí (29 36' W and 51 37'W). Specimens of Girardia anderlani (Kawakatsu and Hauser, 1983) were obtained from Arroio Rolantinho, São Francisco de Paula $\left(29^{\circ} 39^{\prime} \mathrm{S}\right.$ and $\left.51^{\circ} 00^{\prime} \mathrm{W}\right)$.

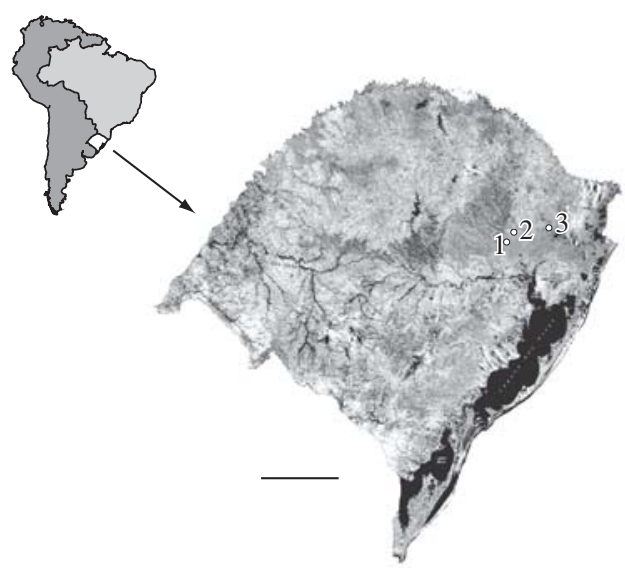

Figure 1. Sampling sites in the northeast region of Rio Grande do Sul State, Brazil: 1) São Sebastião do Caí; 2) Salvador do Sul and São Francisco de Paula; and 3) Gramado. Bar: 100 km.
Chromosome plates were obtained from three days regenerating fragments, immersed in $0.3 \%$ aqueous colchicine solution (SIGMA) for the last three hours. Thereafter, following the method of Hochberg and Erdtmann (1988), tissue fragments were placed in hypotonic solution $\left(0.075 \mathrm{M} \mathrm{KCl}\right.$ preheated to $\left.37^{\circ} \mathrm{C}\right)$, where tissue was cut and crushed using razor and glass pipette in order to form a concentrated suspension of tissue, cells, and sub-cellular material. After 20 minutes, the mixture was resuspended, and centrifuged for five minutes at 800-1,000 rpm, and the hypotonic solution was removed. The concentrate was resuspended in Carnoy fixative (Romeis, 1989), allowed to stand at room temperature for at least one hour, and resuspended, centrifuged for five minutes, and washed with Carnoy solution. This process of centrifugation and washing with fixative was repeated at least three times for a total of at least four washes and centrifugations of each sample. The cell suspension was distributed on pre-frozen glass slides (previously taken from 70 to $90 \%$ ethanol, dried, and frozen), drop by drop from a height of at least $20 \mathrm{~cm}$ causing a "splatter" effect that distributed chromosome complements on the slides while generally maintaining their physical interrelationship. Slides were stained with Giemsa (Romeis, 1989).

The chromosome numbers were evaluated on microscope, and the best metaphase plates were photographed and karyotyped. Representative plates were karyotyped, as were metaphases with hyperploidic chromosome number. Chromosomes were arranged first in terms of form, then in terms of centricity (metacentric grading to submetacentric, and finally to acrocentric), then in decreasing size within each category of centricity. Chromosomes were classified according to Levan et al. (1964).

\section{Results}

The main external features of the investigated populations, as well as a summary of the cytogenetic results, are given in Table 1. Three essential chromosome numerical bases (n) were identified (four, eight, and nine), appearing in two ploidal levels: $2 \mathrm{n}$ and $3 \mathrm{n}$.

Girardia schubarti presents four chromosome pairs (Figure 2a), and the largest element (metacentric) and the smallest element (submetacentric) are very easy to identify. Pairs two and three are similar, corresponding to large submetacentric chromosomes, only possible to differentiate in the best metaphases with elongated chromosomes. The triploid chromosome number is often detected, in totally triploid animals (Figure $2 b$ ) or in mixoploid $2 n / 3 n$ animals (Table 1 ). Thus, three cytotype forms can be detected in G. schubarti, the diploids $2 \mathrm{n}$, the triploids $3 \mathrm{n}$, and the mixoploids $2 \mathrm{n} / 3 \mathrm{n}$. The diploid specimens are larger, while the total or partial triploids are smaller and thinner, but no clear morphologic differences can be seen between the mixoploid and the triploid animals (Table 1).

Girardia tigrina presents the basic diploid complement of eight chromosome pairs (Figure 2c, d). The 
Table 1. External anatomical features and inter and intraspecies chromosome variability of Girardia schubarti, G. tigrina, G. anderlani, and G. biapertura from southern Brazil.

\begin{tabular}{|c|c|c|c|c|c|}
\hline Species & Dorsum morphology & Head morphology & Size $(\mathbf{m m})$ & Ploidy & Observations \\
\hline $\begin{array}{l}\text { G. schubarti } \\
\text { (diploid) }\end{array}$ & $\begin{array}{l}\text { Blackish brown with fine } \\
\text { grayish black pigments; with } \\
\text { or without a longitudinal } \\
\text { black median stripe }\end{array}$ & $\begin{array}{l}\text { Marked triangular } \\
\text { shaped with long and } \\
\text { pointed auricles }\end{array}$ & $\begin{array}{l}\text { up to } \\
25 \times 2.5\end{array}$ & $2 n=8$ & $\begin{array}{l}\text { No chromosome } \\
\text { dimorphism }\end{array}$ \\
\hline $\begin{array}{l}\text { G. schubarti } \\
\text { (mixoploid) }\end{array}$ & $\begin{array}{l}\text { Grayish black with fine black } \\
\text { pigments and mottled with } \\
\text { sparse bright gray spots }\end{array}$ & $\begin{array}{l}\text { Marked triangular } \\
\text { shaped with long and } \\
\text { pointed auricles }\end{array}$ & $\begin{array}{l}\text { up to } \\
13 \times 1.5\end{array}$ & $\begin{array}{l}2 n=8 \\
3 n=12\end{array}$ & $\begin{array}{l}\text { No chromosome } \\
\text { dimorphism }\end{array}$ \\
\hline $\begin{array}{l}\text { G. schubarti } \\
\text { (triploid) }\end{array}$ & $\begin{array}{l}\text { Brownish black with fine } \\
\text { black pigments and mottled } \\
\text { with sparse bright gray spots }\end{array}$ & $\begin{array}{l}\text { Marked triangular } \\
\text { shaped with long and } \\
\text { pointed auricles }\end{array}$ & $\begin{array}{l}\text { up to } \\
12 \times 1\end{array}$ & $3 n=12$ & $\begin{array}{l}\text { No chromosome } \\
\text { dimorphism }\end{array}$ \\
\hline $\begin{array}{l}\text { G. tigrina } \\
\text { (diploid) }\end{array}$ & $\begin{array}{l}\text { Pale brown with numerous } \\
\text { blackish and whitish small } \\
\text { pigments; with or without } \\
\text { a light longitudinal median } \\
\text { stripe }\end{array}$ & $\begin{array}{l}\text { Bluntly triangular } \\
\text { shaped with broad } \\
\text { and short auricles }\end{array}$ & $\begin{array}{l}\text { up to } \\
12 \times 2\end{array}$ & $2 n=16$ & $\begin{array}{l}\text { Dimorphism in } \\
\text { pair } 6\end{array}$ \\
\hline $\begin{array}{l}\text { G. anderlani } \\
\text { (diploid) }\end{array}$ & $\begin{array}{l}\text { Brownish with fine dark } \\
\text { brown pigments and mot- } \\
\text { tled with sparse bright brown } \\
\text { spots }\end{array}$ & $\begin{array}{l}\text { Bluntly triangular } \\
\text { shaped with moder- } \\
\text { ately pointed auricles }\end{array}$ & $\begin{array}{l}\text { up to } \\
20 \times 2\end{array}$ & $2 n=18$ & $\begin{array}{l}\text { Pair } 3 \text { is } \\
\text { submetacentric }\end{array}$ \\
\hline $\begin{array}{l}\text { G. biapertura } \\
\text { (diploid) }\end{array}$ & $\begin{array}{l}\text { Brown with fine dark brown } \\
\text { pigments and sparse pale } \\
\text { brown spots }\end{array}$ & $\begin{array}{l}\text { Bluntly triangular } \\
\text { shaped with moder- } \\
\text { ately pointed auricles }\end{array}$ & $\begin{array}{l}\text { up to } \\
20 \times 2\end{array}$ & $2 n=18$ & $\begin{array}{l}\text { Pair } 3 \text { is } \\
\text { metacentric }\end{array}$ \\
\hline
\end{tabular}

chromosomes are large and decrease continuously in size. The centricity also varies continuously from nearly metacentric to clearly submetacentric. The first and largest chromosome pair is nearly metacentric, as also are several others, but it is difficult to make a clear separation between nearly metacentric and submetacentric elements. The chromosome pairs were arranged in decreasing size. Centricity for the Gramado population was generally six pairs of nearly metacentric and two pairs of distinctly submetacentric (i.e. 6:2) (Figure 2c). Within the laboratory stock at UNISINOS, complements of five pairs of nearly metacentric chromosomes and three pairs of submetacentric (i.e. 5:3) (Figure 2d) were identified, although $6: 2$ proportions also occurred.

Two species, Girardia biapertura and G. anderlani, show the basic number of nine chromosomes with very similar karyotypes. Girardia biapertura presents the four larger pairs nearly metacentric, four smaller submetacentrics, and one median acrocentric pair (Figure 2e). The difference in the karyotype between $G$. anderlani and $G$. biapertura is in the third pair, which is typically submetacentric in G. anderlani (Figure 2f), while nearly metacentric in $G$. biapertura (Table 1). As this is not a notorious difference, it can be noted only in the best metaphases and in a systematic analysis. In a random evaluation of the mixed karyotypes of both species, all the karyotypes differentiated by the third pair were also correctly associated to the species. Neither triploids nor stable mixoploids were found in either species.
(1) If if

(b) 111 $896 \quad 188 \quad 38$

c)

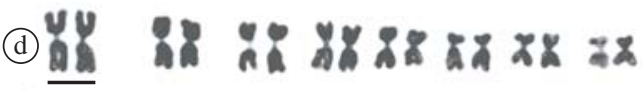

(e) If II IX kis is il

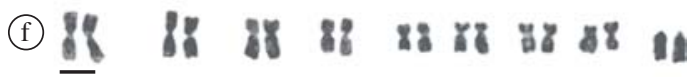

Figure 2. Karyotypes of four Girardia species. a, b) Girardia schubarti, a) diploid $(2 \mathrm{n}=8)$ and b) triploid specimens $(3 \mathrm{n}=12)$; c, d) Girardia tigrina, diploid specimen $(2 \mathrm{n}=16)$ from c) Gramado and d) from a laboratory stock at UNISINOS; e) Girardia biapertura, diploid specimen $(2 \mathrm{n}=$ $18)$; and f) Girardia anderlani, diploid specimen $(2 \mathrm{n}=18)$. Bar: $10 \mu \mathrm{m}$. 


\section{Discussion}

Exact distinction between specifically metacentric and minimally submetacentric or even highly submetacentric chromosomes was difficult for a number of reasons. The same chromosome complement, even within members of the same chromosome pair, might distribute differently during the dispersion or separation process thus presenting not so similar appearances. Minor variations among cells of the same specimens are also noted, but chromosome variability is decided on stable difference in a group of cells or animals.

The three groups of karyotypes $(n=4, n=8$, and $\mathrm{n}=9$ ) identified in the present study show distinct chromosome morphology. All karyotypes were multiples of these three distinct chromosome complements. Haploids were not considered, neither were the highly unstable tetraploids resulting from intracellular chromosome endoreduplication. Other complicating factors such as the presence of supernumerary chromosomes "A" or "B" were noted but do not fall within the scope of this report.

The first group $(n=4)$, corresponding to specimens of G. schubarti, contained three distinct subgroups (pure diploid, mixoploid diploid-triploid, and pure triploid). Specimens from populations of G. schubarti in South Brazil have been previously identified and karyotyped by Kawakatsu et al. (1984), including diploid specimens, diploid-triploid mixoploids, at least one tetraploid specimen, diploid-tetraploid specimens, and at least one diploid-triploid-tetraploid specimen. The body size differences that were observed in the present study between diploids and total or partial triploids are notorious at the first glance. The specimens with total or partial triploidy cannot be differentiated merely by their external morphology, which is in agreement with the results of a quantitative analysis done by Knakievicz et al. (2006). Aside from ploidy, no variability in the chromosome morphology was detected. Compared to clonal diploids, polyploid specimens show greater tolerance to mutation load or increased genetic plasticity (Beukeboom et al., 1998). However there is no reference concerning the origin of the genetic plasticity of the partial or total triploids, whether they are stable lines or originated constantly de novo.

The second category, containing two populations of Girardia tigrina, shows specimens presenting stable diploid karyotypes with an essential chromosome complement structured on eight basic chromosome forms or polymorphisms. As also found in G. schubarti, all chromosomes were biarmed. No acrocentrics or even small submetacentrics were present. This total lack of acrocentric chromosomes distinguished this group and species from all others in the study, mainly from the most similar G. anderlani group.

The 5:3 and 6:2 centricity ratios (nearly metacentric:submetacentric) for $G$. tigrina coincided closely with the descriptions given by Benazzi and Lentati (1976) that addressed the karyology of G. tigrina in terms of similarities and inequalities in length of chromosome arms without using centricity classification. However, their description clearly indicates a centricity ratio of at least six metacentric to two submetacentric chromosomes. It also coincides with the work of Ribas et al. (1989), concerning a population of this species from the western Mediterranean region in which the chromosome morphology is clearly in a $6: 2$ proportion. The chromosome variability detected between the two populations of $G$. tigrina is small and visible only in the best metaphases. Kawakatsu et al. (1981) described a 7:1 proportion of metacentric to submentacentric. Further research is required to confirm this genetic plasticity in this species.

The third group has the same basic number $(n=9)$ and very similar chromosome morphology for both representative species, G. biapertura and $G$. anderlani. It showed essential chromosome complements structured on some multiples of nine basic chromosome forms. It usually presented eight biarmed chromosomes and one pair of large acrocentric chromosomes as markers. The karyotypes of this group presented chromosome morphologies similar to those previously reported for G. anderlani by Kawakatsu et al. (1983) that did not recognize the acrocentric chromosomal form specified herein, treating it as a degree of submetacentric. They did however encounter mixoploid $2 n / 3 n$ specimens. Previous research within the western hemisphere (Gourbault, 1979) clearly recognized and distinguished the acrocentric form in the species Girardia cubana (Codreanu and Balcesco, 1973) classifying it as "sub-telocentric". Acrocentric chromosomes are rare in the family Dugesiidae and were also reported for Cura foremanii and species of Schmidtea (Gourbault and Benazzi, 1975; De Vries and Sluys, 1991).

The great similarities in the second and fourth chromosome pairs of $G$. biapertura and $G$. anderlani deserve further investigations. The morphologic difference between the third chromosome pair of these two species, probably caused by a chromosome pericentric inversion, serves as a cytotaxonomic character to distinguish these species and may be used as a phylogenic reference (although not absolute in itself). This further raises questions regarding the genesis, development, and taxonomic proximity of the two species.

Previous studies have reported intraorganismal genetic plasticity (e.g. at least one stable mixoploid specimen) for G. anderlani (e.g. diploid $2 \mathrm{n}=18$, and triploid $3 n=27$ specimens) (Kawakatsu et al. 1983; Knakievicz et al., 2007), interorganismal (i.e. intraspecific), and intraorganismal genetic plasticity for G. schubarti (e.g. diploid $2 n=8,3 n=12,4 n=16$ specimen; $2 n$, $4 n$ specimen, and 2n, 3n specimens) (Kawakatsu et al., 1984), and pure triploids of both species and of G. tigrina (Knakievicz et al., 2007). The population of pure triploid (i.e. $3 \mathrm{n}=12$ ) specimens of $G$. schubarti found at Linha Júlio de Castilho (municipality of Salvador do Sul, Rio Grande do Sul State), in addition to those sampled by 
Knakievicz et al. (2007) in two other localities, emphasizes, amplifies, and serves as a further reference to the occurrence and level of genetic plasticity (especially at the intraspecific, interorganismal level) in specimens of this species originating from populations found in this region of Brazil. High variability of genetic plasticity and/or high genetic variance may serve as tools in determining phenotypic plasticity for populations under specific environmental conditions and/or within specific geographic regions.

Chromosomal polymorphic centricity factor (CPCF) proportions can vary between individual specimens of the same species (i.e. interorganismal, intraspecific variation) (Benazzi and Lentati, 1976; Kawakatsu et al., 1981), or even between cells of different ploidy level (i.e. mixoploid, genetic plasticity) within the same specimen (i.e. intraorganismal, intraspecific variation). Such intraorganismal intraspecific variation in CPCF proportions raises questions concerning the genesis and maintenance of mixoploid individuals. Ploidy (i.e. multiplicity) of these basic chromosomal combinatorial values, both within and between individuals, is a quantitative criterion for distinguishing populations within species or groups. However, chromosomal size differences within any one of these polymorphic criteria present major complicating factors.

Acknowledgments - We are grateful to Conselho Nacional de Desenvolvimento Científico e Tecnológico (CNPq) for research grants. We also thank the laboratorial technician Teresinha $\mathrm{H}$. Oliveira for photographical work and MSc. Zênia Heller who collaborated with specimen collecting. Fabiano Gil and Vanessa Baptista are acknowledged for his help with the preparation of the final version of the figures. We thank Prof. Dr. Masaharu Kawakatu for comments and suggestions on an early draft of the manuscript.

\section{References}

BENAZZI, M. and LENTATI, GB., 1976. Platyhelmintes. Animal Cytogenetics, vol. 1, p. 1-182.

BEUKEBOOM, LW., SHARBEL, TF. and MICHIELS, NK., 1998. Reproductive modes of ploidy distribution, and supernumerary chromosome frequencies of the flatworm Polycelis nigra (Platyhelminthes: Tricladida). Hydrobiologia, vol. 383 , p. $277-285$.

DEVRIES, EJ. and SLUYS, R., 1991. Phylogenetic relationships of the genus Dugesia (Platyhelminthes, Tricladida, Paludicola). J. Zool. Lond., vol. 223, p. 103-116.

GIRARD, C., 1850. A brief account of the fresh-water planariae of the United States. Proc. Boston Soc. Nat. Hist., vol. 3, p. $264-265$.

GOURBAULT, N., 1979. Données biologiques et cytotaxonomiques sur un triclade de l'ile de Cuba. Archiv. Zool. Exp.Gén., vol. 120, p. 131-142.
GOURBAULT, N. and BENAZZI, M., 1975. Karyological data on some species of the genus Cura (Tricladida, Paludicola). Can. J. Genet. Cytol., vol. 17, p. 345-354.

HOCHEBERG, VBM. and ERDTMANN, B., 1988. Cytogenetical and morphological considerations on Rhamdia quelen (PISCES, PIMELODIDAE) - the occurrence of $\mathrm{B}$ chromosomes and polymorphic NOR regions. Braz. J. Genet., vol. 11, p. $563-567$.

KAWAKATSU, M., OKI, I., TAMURA, S., YAMAYOSHI, T., HAUSER, J. and FRIEDRICH, SMG., 1981. Morphological, karyological and taxonomic studies of freshwater planarians from south Brazil. II. Dugesia tigrina (Girard, 1850) (Turbellaria, Tricladida, Paludicola). Bull. Fuji Women's Coll. vol. 19, Ser II, p. 113-136.

KAWAKATSU, M., HAUSER, J. and FRIEDRICH, SMG., 1983. Morphological, karyological and taxonomic studies of freshwater planarians from south Brazil. IV. Dugesia anderlani sp. nov. (Turbellaria, Tricladida, Paludicola), a new species from São Leopoldo in Estado de Rio Grande do Sul. Annot. Zool. Jap. vol. 56, p. 196-208.

KAWAKATSU, M., OKI, I., TAMURA, S., YAMAYOSHI, T., HAUSER, J. and FRIEDRICH, SMG., 1984. Morphological, karyological and taxonomic studies of freshwater planarians from south Brazil. VI. Dugesia schubarti (Marcus, 1946) from the vicinity of São Leopoldo, Estado de Rio Grande do Sul (Turbellaria, Tricladida, Paludicola). Bull. Fuji Women's Coll., vol. 22, ser II, p. 45-62.

KNAKIEVICZ, T., VIEIRA, SM., ERDTMANN, B. and FERREIRA, HB., 2006. Reproductive modes and life cycles of freshwater planarians (Platyhelminthes, Tricladida, Paludicola) from southern Brazil. Inv. Biol., vol. 125, no. 3, p. 212-221.

KNAKIEVICZ, T., LAU, AH., PRÁ, D. and ERDTMANN, B. 2007. Biogeography and karyotypes of freshwater planarians (Platyhelminthes, Tricladida, Paludicola) in southern Brazil Zool. Sci., vol. 24, no. 2, p. 123-129.

LEVAN, A., FREDGA, K. and SANDBERG, AA., 1964 Nomenclature for centromeric position of chromosomes. Hereditas, vol. 52, p. 201-220.

MARCUS, E., 1946. Sôbre Turbellaria brasileiros. Bol. Fac. Fil. Ciênc. Letr. Univ. São Paulo, série Zoologia, vol. 11, p. 5-254.

PEREIRA, MEQ., 1970. Método para estudo de cromossomos em planárias. Ciência e Cultura, vol. 22, no. 3, p. 211-212.

RIBAS, M., RIUTORT, M. and BAGUÑA, J., 1989 Morphological and biochemical variation in populations of Dugesia (G.) tigrina (Turbellaria, Tricladida, Paludicola) from the western Mediterranean: biogeographical and taxonomical implications. J. Zool. Soc. London, vol. 218, p. 609-626.

ROMEIS, B., 1989. Mikroskopische Technik. 17. edition. Urban und Schwarzenberg, München, 697p.

SLUYS, R., HAUSER, J. and WIRTH, QJ., 1997. Deviation from the groundplan: a unique new species of freshwater planarian from South Brazil (Platyhelminthes, Tricladida, Paludicola). J. Zool. Lond., vol. 241, p. 593-601. 
